folk/ed. Derg, 2020; 26(2):249-264

DOI: $10.22559 /$ folklor.1179

\title{
Farklı Yaşlar Benzer Kareler
}

\author{
Different Ages, Similar Frames
}

\section{Çiğdem Kara* \\ M. Muhtar Kutlu**}

\begin{abstract}
$\ddot{O} \mathbf{z}$
Doğum günü fotoğrafı çektirme, doğum günü ritüeline eklenmiş modern bir gelenek olup aile fotoğrafı türü içinde değerlendirilir. Makalede, aynı ailenin iki farklı kuşağından dört çocuğun doğum günlerine ait 1960'lar ve 1990'ların ilk yarısından yedi fotoğraf incelenmektedir. Makalede, farklı yaşlardan farklı kişilerin doğum günü fotoğraflarının neden benzer bir kareye sahip olduğu sorusuna yanıt aranmaktadır. Fotoğraflar, Panofsky'nin ikonolojik ve ikonografik yöntemlerinden yararlanılarak incelenmektedir. Ama fotoğraflar değerlendirilirken, insanbilim alanının ana soru ve terimlerinin oluşturduğu bir bakış açısı kullanılmaktadır. Fotoğrafların sahibi, biyografisi sözlü olarak kaydedilmiş olan Mustafa Muhtar Kutlu'dur. $\mathrm{Bu}$ nedenle fotoğrafların anlamı, fotoğraflardaki gizli olan kişisel deneyimler ve özgünlükler, fotoğraf sahibinin biyografisi aracılığıyla açığa çıkarılmaktadır. Makalede benzer karelerin, üç kalıbın uygulanmasıyla oluştuğu ileri sürülmektedir. Bu kalıplardan ilki, portre sanatı kadar halk sanatında da kullanılan kalıp-tasvirdir. Diğer iki kalıbı ise fotoğrafların çekilme nedeni olan ritüel ve aile imgesi oluşturmaktadır. Bu üç tasvir kalıbı fotoğrafları ilk bakışta anlaşılabilir kılmaktaysa da
\end{abstract}

Geliş tarihi (Received): 22.01.2020 - Kabul tarihi (Accepted): 15.04.2020

* Doç.Dr., Anadolu Üniversitesi Edebiyat Fakültesi / Türk Dili ve Edebiyatı Bölümü / Halkbilim (Folklor) Anabilim Dalı. cigdemk@anadolu.edu.tr. ORCID ID: 0000-0002-6059-6382

** Prof.Dr., Ankara Üniversitesi, DTCF. Halkbilim Bölümü. muhtarkutlu@yahoo.com. ORCID ID: 0000-00029278-5647. 
onların değerini belirleyen tek etken değillerdir. Çeken gözün yaratıcılığı ve biraz şans, fotoğrafları estetik açıdan özgünleştiren unsurlardır. Anlamsal değerse hem fotoğrafların yansıttığı imgelerin etnografik nitelikleri, hem de sahiplerinin onlara sığdırdığg anılarla ilgilidir.

Anahtar sözcükler: aile fotoğrafi, kalıp tasvir, doğum günü, biyografi

\begin{abstract}
Birthday photographing is a modern tradition that attached to birthday ritual, and considered within the family photograph type. In this article, seven photos of birthday celebrations from first half of 1960s and 1990s that they are belong to same family' four children from two different generations, are examined. And problem is why birthday photos of different persons from different ages have similar frames. The photos are analyzed by Panofsky's iconographic and iconological methods. However, a perspective formed by the main questions and terms of anthropology is used while analyzing photographs. The owner of the photos is Mustafa Muhtar Kutlu, whose biography was recorded orally. Therefore, the meaning of the photographs, the personal experiences and authenticities hidden in the photographs are revealed through the biography of the owner of the photographs. In the article, it is claimed that practiced three patterns creates the similar frames. One of these patterns is schemata which uses portrait art and also folk art. The other two patterns are created by ritual and family image that these are reasons of the taking the photographs. Although these three patterns make the photos understandable at first glance, they are not the only factor that determines their value. The creativity of the eye that shoot the photographs and a bit of luck are elements that make the photos aesthetically unique. Semantic value is related to both the ethnographic characteristics of the images reflected by the photographs and the memories that the owners fit them.
\end{abstract}

Keywords: family photography, schemata, birthday, biography

\title{
Extended abstract
}

The subject of this article is meaning of seven birthday ceremony photographs. Five of the photos are from folklorist, ethnologist professor Mustafa Muhtar Kutlu himself and his sister's birthdays in the 1960s, the other two is from Kutlu's daughter and son's birthdays in the first half of the 1990s. Almost all of the photos have a similar composition: A table, children (in the five) or children and adults (in the two) gathered around the table, birthday cake with a candle in the center of the table, different food and fruits, clean and empty plates and glasses. The aim of the article is to seek why these birthday ceremony photos have a similar frame, although they were shot at different year and they belonged to different people who different ages. The photographs are analyzed by Panofsky's (1995) iconological and iconographic methods. But the photographs are interpreted based on the main questions and terms of folklore and anthropology.

In order to interpret the photographs, as a first, the images in the photographs are determined. Secondly, the expressions of the images in the photographs is examined. Some expression of the images are as the follow: In one of the photograph consisting of only 
two children images, the children look at the candle flame almost admiringly. Only two photographs are able to capture the flow of the ceremony. These two photographs show the moment of candle blowing. All photographs are able to capture excitement, unstoppable laughs, astonishment, enthusiastic applause, and candle blowing race of the children.

The third subject that examined is the symbols. Because what distinguishes these photographs from an ordinary family photo or group portrait is the symbols specific to the birthday ritual. The symbols in the photos realized at first glance are: Birthday cake with candles, candle flame, cake decoration and writings on it, candle blowing, sugary foods and, semi-formal dress of children.

Fourthly, the context and the invisible background of the photographs and, the continuity of the event in the photographs are emphasized through memories. In this section, in addition to Panofsky, Hirsch's (1997) familial look term is also used. Kutlu's memories can be gathered in five themes: Photographers, guests, houses where the ceremony was held, gifts and baking the cake. The prominent parts of the memories can be summarized as follows: Kutlu's family had a camera. They could take photos themselves, but they also called a professional photographer. That is why they had a rich family photo albums. The photos of the birthday ceremonies were put in family albums to show guests, and posted to close friends and distant relatives. In accordance to social functions of birthday ceremony, the guests of the birthday ceremony were not only the friends of the birthday's children but also their parent's friends, neighbors, and relatives. Almost all photographs were taken in different houses, and even in different cities, due to the job of the children's fathers. Although gifts are not seen in the photographs, Kutlu remembers two gifts: One was a mind game that his father presented. The other was a book about the biological and cultural diversity of the human given by a friend of his father. The birthday cake of Kutlu's and his sister's baked by their mother. The birthday cake of Kutlu's and his sister's, was baked by their mother. In connection with this memoir, Kutlu also recalled his father's travel to the USA and, the pastry making tools, refrigerator and tablecloth that his father brought with him on his travel trip.

The article suggests that similar frames are formed by applying three patterns. The first of these patterns is Gombrich's (2015) concept of schemata, it is called also pattern system by Burke (2003). Schemata is used in portrait art as well as folk art for an aesthetic forms by emulate and reproduce techniques (Jones, 1997). The source of the other two patterns is the ritual and family image. Taking a birthday photo is a modern tradition that has been added to the birthday ritual and is considered as a family photo type. For this reason, the composition in the photographs has a schemata to reflect the main elements of the ritual. The image of the family also provided a schemata for photographs to reflect the unity, order, interest and inner relationships of the family. Although these three patterns make the photos understandable at first glance, they are not the only factor that determines their value. The creativity of the eye that shoot the photographs and a bit of luck are elements that make the photos aesthetically unique. Semantic value is related to both the ethnographic characteristics of the images reflected by the photographs and the memories that the owners fit them. 


\section{Giriş}

2015 yılında, bir sözlü biyografi kaydı sırasında, biyografi sahibi özne doğum günü kutlamalarından bahsederek bir dizi fotoğraf ortaya çıkarmıştı. ${ }^{1}$ Anna ve Richard Wagner çiftinin Noel fotoğrafları serisini hatırlatan (Draaisma, 2012: 146-56) bu fotoğrafların ilk beşi 1960'lı yılların, son ikisiyse 1990'ların ilk yarısında renkli çekilmişti. Bir ailenin üçüncü kuşağından iki çocuğun ve bu çocuklardan birinin yıllar sonra kurduğu ailede doğan iki çocuğun doğum günlerini yansıtıyorlardı. Fotoğraflardaki masa düzeni neredeyse aynıydı. Ama büyüyen çocuk bedenleri zamanın ilerlediğini anlatıyordu. Wagnerlerin yaptığı gibi, fotoğraflar çoğaltılıp yakın arkadaşlara dağılmış, ailenin "uzak memleketteki” akrabalarına yollanmıştı. Fotoğrafların genel betimi, sahiplerinin sözleriyle şöyledir: "Bir masa. Masanın etrafındaki sokaktaki, mahalledeki arkadaşlarım; kızlı erkekli. Önümüzde annemin yaptığı bir pasta. Üstünde mumlar. ...ben büyüyorum ama hep o fotoğraf, o tür pozlar var; bir evde, başka bir evde..." İnsanların pozları neden aynıdır? Geçen yıllara rağmen fotoğraflardaki kurgu neden aynı kalmıştır?

Kültürün, tarihsel süreçte seçilerek ortaya çıkmış, topluluğa bir birlik kazandıran toplumsal referans ya da çerçevelerden, geniş çapta da evrensel kalıplardan oluştuğu kabul edilirse (Kroeber ve Kluckhohn, 1952: 163), benzer karelerin çekilmesinin nedenleri de toplumun ortak referansları, çerçeveleri ve -daha geniş bir bakış açısından- evrensel kalıplar olacaktır. Benzer kareler de insanın evrenselliğine verilebilecek sayısız örnekten biridir. Ama bu benzerliği yaratan kalıp ya da kalıplar neler olabilir? Makalede bu sorunun yanıtı disiplinlerarası bir çerçeveden aranmaktadır.

\section{Fotoğrafi okumak}

Etnografların “metne olan düşkünlük”leri yüzünden görsel malzemelerin etkisi, araştırmaların “sonuç aşamasında yeterince görülmez"se de, alanda 1800'lü yıllardan beri görsel malzemeler veri kaynağı, belge olarak kullanılmaktadır (Yıldırım, 2013: 112, 119). Bu yazı açısından da fotoğraflar birer etnografik bilgi kaynağı olup çözümlemede kullanılan yöntem Panofsky'nindir (1995: 27-32). Buna göre, birincil konu - olgusal okumada, çerçevedeki imgeler betimlenirken, anlatımsal okumayla yansıttıkları duygu ve ilişkilerle ilgili izlenimlerle çekim anının kesintiye uğrattığı akışın nasıl olabileceği de anlatılmaktadır. İkincil ya da uzlaşımsal konu okumasında fotoğraflara yansıyan ritüel ve simgelere değinilmektedir. İkonolojik yorum (içsel anlam ya da içerik) aşamasındaysa fotoğrafların anlamı, içinden çıkarılıp alındıkları bağlamla, o bağlamdaki işlevleriyle ve onlara atfedilen tarihle ortaya çıkarılmaktadır. Bunun için de fotoğrafların sahibinin biyografisine başvurulmaktadır. Çünkü fotoğraflar, zamanın bir anını durduran, süreksiz bellekler olduğundan, "kendi başlarına hikâye anlatmazlar" (Berger, 2015: 72-3, 76, 78, 84, 94, 115).

\section{II. İmgeler}

Aşağıda çözümlenen fotoğraflardaki imgeleri fark edebilmek için şu dört niteliğe bakılmıştır: Bir, çerçevenin içindeki yakın ya da uzak duruşların ifade ettiği bireyler arası ilişkiler, toplumsal mesafe. İki, cephe, eğik, dikey gibi açıların göstergesi olduğu öznel tutum. Üç, fotoğrafı çekilenlerin fotoğrafı çekenle etkileşimi, kameraya bakışı. Dört, gerçekçi ya da soyutluk gibi fotoğrafin tarzı (Kress ve Van Leeuwen 2001, akt, Wang vd., 2014:. 197-8). 


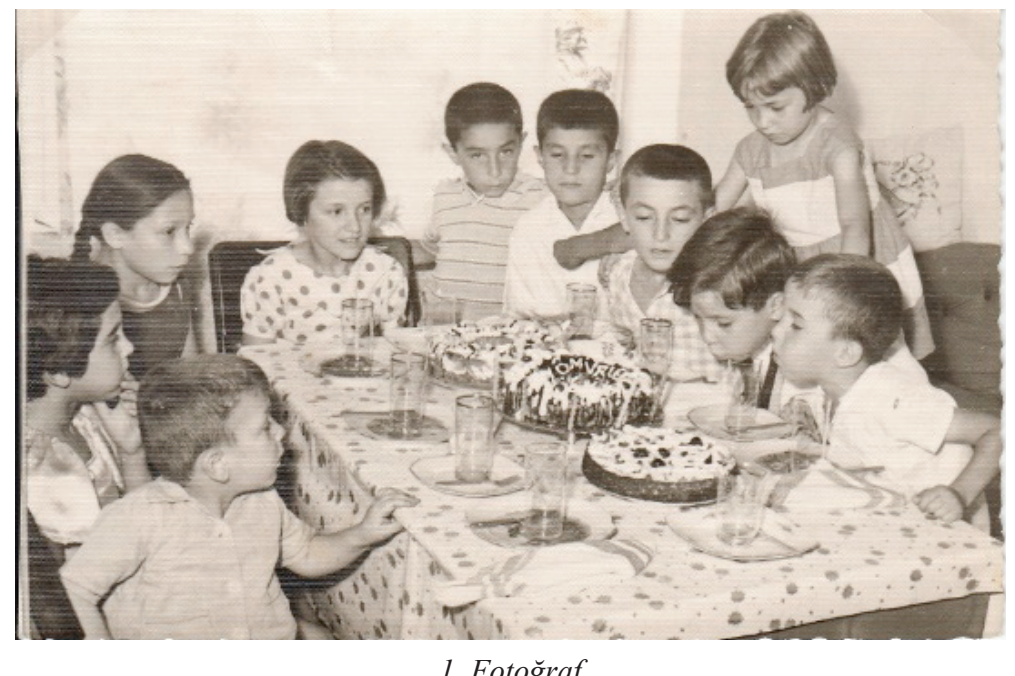

1. Fotoğraf

1. fotoğrafta evin salonundaki masanın etrafinda geçen bir doğum günü görülmektedir. Farklı yaştan dört kız, altı oğlan, masanın üç kenarına oturmuş. Masanın bir kenarı olasılıkla fotoğraf çekimi için boşaltılmış. İki çocuk hala mumların peşinde. Çocuklar pastayı üfleyen ikiliyi gözlüyor. Sadece bir çocuk kameraya kilitlenmiş durumda ve ayakta. Küçük bir kız ayakta, oturan, kendinden büyüklerin omuzlarının ardından mumların söndürülüşünü izliyor. Masa oldukça düzenli: Desenli masa örtüsü, üç pasta, tabakların içinde bardaklar ve hemen yanında çatal. Masanın her iki yanında birer büyük bez peçete. Ortadaki büyük doğum günü pastasının üzerine yazılmış, bir dönemin kalıp ifadesi seçiliyor; “... ömürler...”.

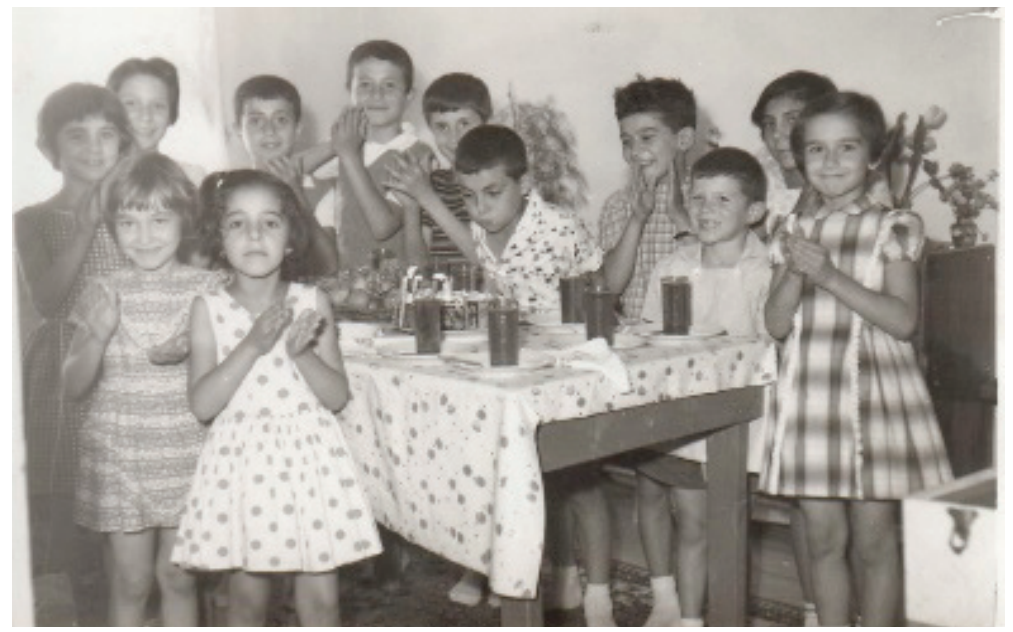

2. Fotoğraf 
2. fotoğraf, ilk fotoğraftan farklı bir evde çekilmiş. Ama doğum günü yine evin salonunda ve bir masanın etrafında geçmekte. Farklı yaştan altı kız, altı oğlan ayakta, yine masanın üç kenarına dizilmişler. Sol en öndeki ve sağdan ikinci imgeler, 1. fotoğraftakilere eklenmiş yeni kız konuklar. Çocukların yüzleri kameraya dönük. Eller alkış halinde. Ama üç çocuğun dikkati dağılmış: Biri, pastayı üflüyor; alkışlar ona. Diğeri de ona bakıyor ama bir taraftan da alkışlıyor. Üçüncüsüyse odanın karede görünmeyen bir tarafına bakıyor. Elleriyse görünmüyor. Masa düzenli: Desenli masa örtüsü, çeşitli meyvelerle dolu bir meyve tabağı, servis tabağ 1 içinde bardak ve çatal yan yana. Masanın başındaysa bir bez peçete.

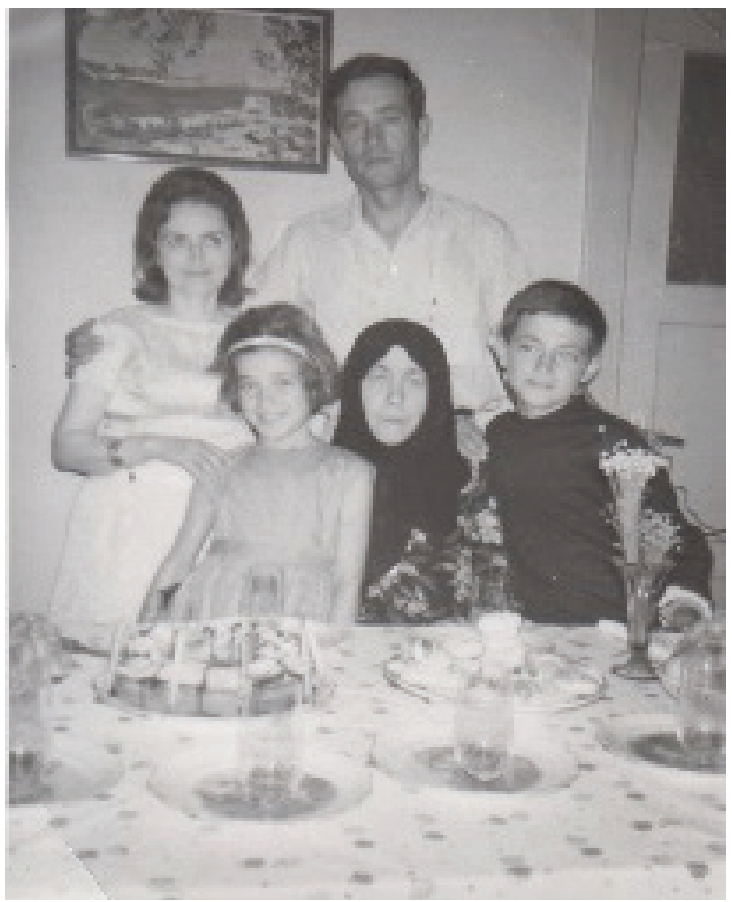

3. Fotoğraf

3. fotoğraf, diğer iki fotoğraftan farklı bir evde, ama yine evin salonunda çekilmiş. Masanın önünde durduğu duvarın üstünde bir tablo asılı. Beş kişi masanın tek kıyısında birleşerek poz vermiş. Üç farklı yaş grubu bir arada. Fotoğrafın ortasında yer alan ve oturan tek kişi olan ilk yaş grubu ve onun iki yanındaki kendisine yapışık duran üçüncü yaş grubu aynı hizada. İkinci yaş grubu arka sırada, ayakta. Fotoğraftaki az sayıdaki kişinin birbirine sokulmasının ve ayakta duranların yetişkin olmasının etkisiyle fotoğraf dik çekilmiş. Masa düzeni diğerleriyle aynı: Desenli masa örtüsü, doğum günü pastası, kurabiye dolu bir başka büyük tabak, servis tabakları içinde henüz boş olan bardaklar. 


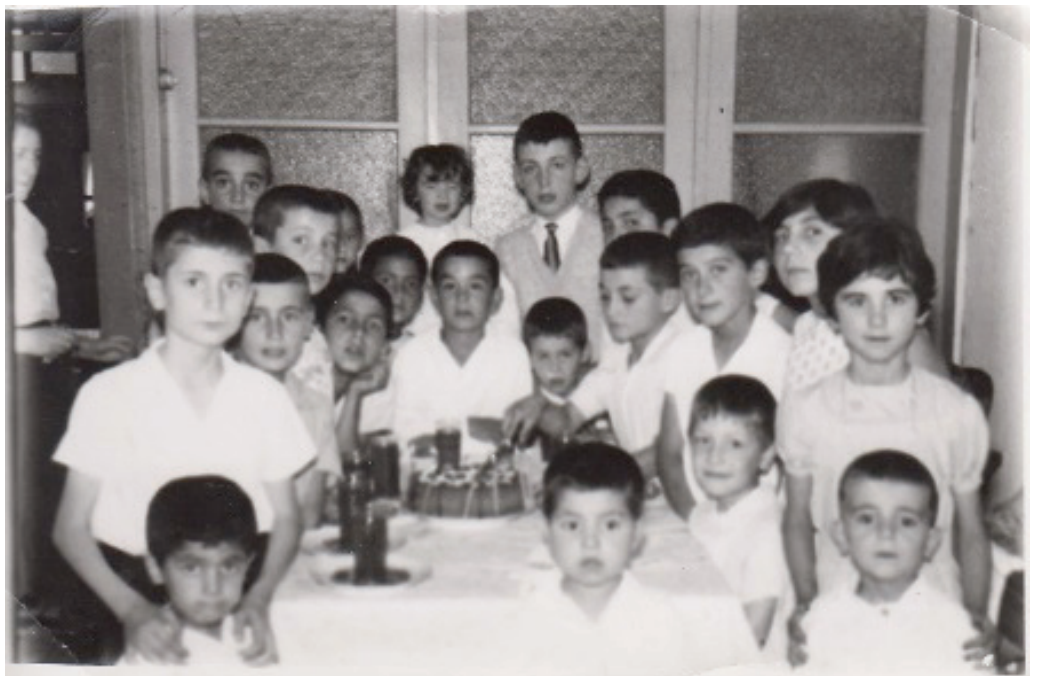

4. Fotoğraf

4. fotoğraf, yine farklı bir evin salonunda çekilmiş. On beş oğlan, beş kız çocuğu, salona açılan bir başka odanın camlı kapısının önündeki masanın dört yanında ayakta dizilmiş. Birbirlerine sokulmuşlar ve aradan baş uzatanlar olmuşsa da hepsi karede tam çıkmamış. Solda küçük bir kızın yüzünün yarısı, sağdaysa bir oğlanın sadece gözlerinden yukarısı çıkmış. Küçükler öne ve olasılıklar en arkada yüksek bir yere yerleştirilmiş. Uzunlar iki yanda sıkışık bir biçimde ayakta durmuş. Herkes açık renk giyinmiş, masa örtüsü de beyaz olunca çocukların yüzleri belirginleşmiş. Çocukların biri hariç diğerleri ne birbirleriyle, ne de doğum günüyle ilgileniyor. Dikkatlerini kameraya vermişler. Ama bir çocuk pastayla ilgileniyor. Elinde bıçak, etrafında mumlar dizili pastayı kesiyor. Masa her zamanki düzeninde: Beyaz masa örtüsünün üstündeki tabaklara konmuş bardaklar dolu.

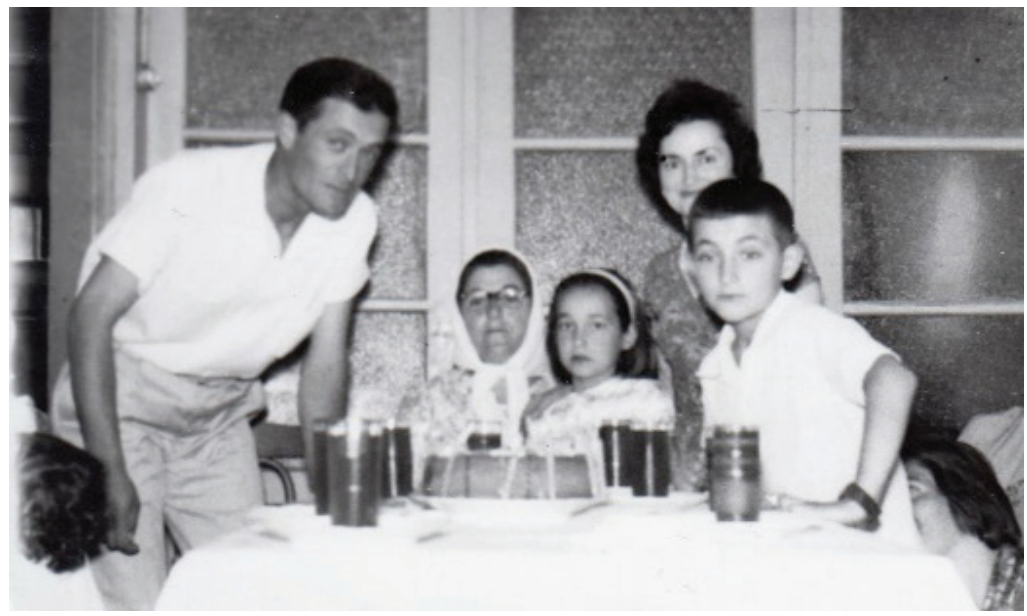

5. Fotoğraf 
5. fotoğraf, 4. fotoğrafla aynı güne ait. Masanın tek kıyısına toplanmış yine üç yaş grubu görülmekte. Kameraya bakan beş kişi olsa da karede aslında altı kişi var. Oğlanın arkasında, yerde, bir kadın oturuyor. Ama yüzünü saklamaya çalışıyor. Merkezde yer alan ve oturan ilk yaş grubunun sağ tarafında kadın ve çocuklar, solunda yetişkin erkek yer almakta. Fotoğraf bu defa yatık pozisyonda alındığından eğilen yetişkin erkek, merkezdeki kadına biraz mesafeli. Merkezdeki kadın üçüncü yaş grubundan kız çocuğunu yanına çekmiş. Arkalarında, ayakta ikinci yaş grubundan kadın duruyor. Yetişkin erkek gibi beyaz gömlek giymiş oğlan da sağ önde ayakta. Masa düzeni diğerleri gibi: Beyaz masa örtüsü üstünde, beyaz tabakların içinde duran renkli işlemeleri olan bardaklar masanın kenarlarına dizilmiş. Dış etrafına mumlar dizilmiş olan pasta ortada, ilk kuşakla fotoğrafın merkezinde yer alıyor.

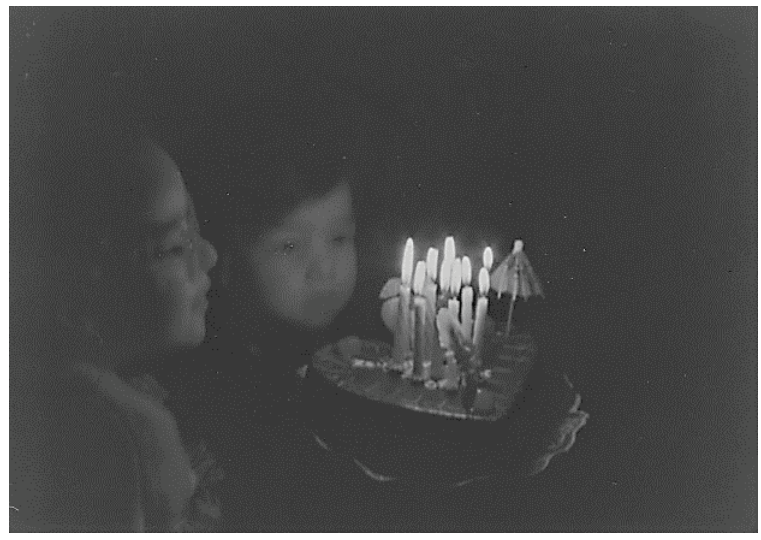

6. Fotoğraf: Evlatlar - 1

6. fotoğraf, ailenin dördüncü kuşağına ait. Biri doğum günü sahibi olan iki çocuk, kalp biçimli pastanın üstündeki yanan dokuz muma bakıyor. Diğer fotoğraflardakilerden farklı olarak mumlar pastanın üstüne yerleştirilmiş. Pasta dekorasyonu olarak bir de küçük şemsiye var. Fotoğrafın karanlık art alanı mekanı belirsizleştirmekte.

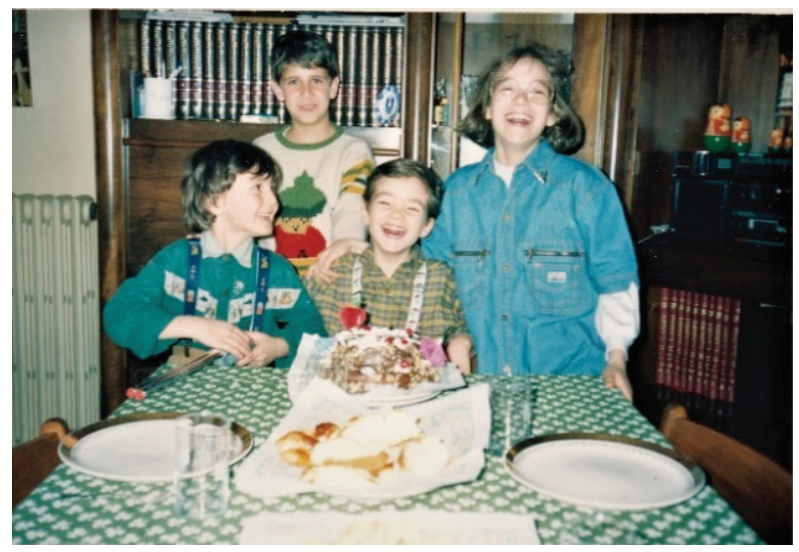

7. Fotoğraf: Evlatlar - 2 
7. fotoğraf, yine ailenin dördüncü kuşağına aittir. İlk beş fotoğraftaki gibi, evin salonunda düzenlenmiş doğum günü masası mekân olarak kullanılmış. Ayakta duran çocuklar masanın dar bir kenarında toplanmış. Ortada, pastanın tam önünde, grubun en küçüğü gibi görünen bir oğlan; omzunda da sağ yanında duran kızın eli var. İkili gülmekte ve kameraya bakmaktalar. Sol öndeki oğlan gülümsemekte ama gülen kızın kahkahaları kameradan daha cazip gelmiş olmalı ki yüzünü çevirmiş kızı izliyor. Sol arkadaki grubun en uzunu, doğrudan kameraya bakmakta. Masa düzeni ilk beş fotoğrafı hatırlatmakta: Masa örtüsü serili bir masa üzerinde temiz boş servis tabakları, bu defa tabakların yanına konmuş olan bardaklar, doğum günü pastası bir başka hamurlu yiyecek.

\section{III. İfadeler}

Birincil konu açısından görsel malzemedeki imgeler sabittir. Ama enstantane fotoğraf sürmekte olan (burada doğum günü ritüel süreci) bir şeyi keserek karta sabitlemektedir. Bu nedenle çerçevedeki figürlerin poz vermesi (kameraya odaklanma) ve kurgu (öznelerin fotoğrafta yer alış biçimi), fotoğrafın anlamı ve estetik gücünü de etkilemektedir. Örneğin, enstantane fotoğrafın, mimik ve duygularla sürekli bir devingenlik halindeki canlı bir yüzün, sadece bir anını yakalayarak yüzü durdurması, bazen yorumlanamaz ifadelere yol açmaktadır (Gombrich, 2015: 116). Bu nedenle makaleye özel aklş² diye ifade edilecek olan kesilmiş sürekliliğe de bakılmaktadır. Maske ifadedense yakalanmıs gülümseme ve seyircinin payını keşfetmek, yani "durdurulmuş imgeye yaşam ve anlatım yansıtma ve fiilen orada olmayanı kendi deneyimimizden ekleme eğilimi” de akışı yakalamanın yolu olarak kullanılmaktadır (Gombrich, 2015: 55, 116-8).

Buna göre, fotoğrafların kurgu açısından güçlü olmadığı ama öznelerin poz vermek üzere yönlendirildiği görülmektedir. Örneğin, 4. fotoğrafta çekimi yapan kişi, kalabalık bir grup çocuğu kadrajına sığdıracak yerleştirmiştir. Ama bu sıkışıklıktaki temaslarda ne bir sıcaklık ne de bir koruyuculuk vardır, sadece ölçülü bir düzen hissedilmektedir. Profesyonel bir gözün çektiği 4. fotoğrafta, 5 . fotoğrafta da olduğu gibi, düzeni bozan ve kurgu pozun parçası olmayan tek kişi, fotoğrafa girdiğinin de farkında olmayan kıyıdaki aile büyükleridir. Bir aile üyesi tarafından çekilen 7. fotoğrafta da bir düzen görülmektedir ama yüzler ve eğilmiş bedenler bireyler arası ilişkilerin daha sıcak olduğunu yansıtmaktadır.

Olay akışında enstantanenin yakaladığı bir gülümseme, devam eden bir heyecanı betimler ve bakanları da bu olay akışına katar. Örneğin pasta üfleme heyecanı ve birden fazla kişinin mumları söndürme hamlesi, alkışlama ve gülme, akışa bağlı eylemler olarak kabul edilirse törenin heyecan dalgasına kapılış, 2. fotoğrafta net olarak görülmektedir: Olasılıkla bir dış uyaranla, gözler objektife çevrilmişse de eller hala alkıştadır. Ama sadece iki kişi tam olarak akıştadır: Doğum günü çocuğu ve hemen sağ arkasındaki arkadaşı. Fotoğrafların hepsinde kurgu, masa ve pasta odağından yapıldığından, fotoğrafların merkezinde genelde doğum günü çocuğu bulunmamaktadır. Örneğin 7. fotoğrafta pastanın tam önünde durması dolayısıyla doğum gününün küçük erkek çocuğunun olduğu iması çıkmaktadır. Davetlilerin arasında kaybolduğu düşünülse de akış doğum günü çocuğunun seçilebilmesini sağlamaktadır. Örneğin, tıpk1 2. fotoğrafta olduğu gibi, 1. ve 4. fotoğrafta doğum günü çocuğu, kurgudan ve grup portresi kalabalığından kendi doğum gününün akışından çıkamayıp objektife 
bakmayarak sıyrılıyor. Bir aile üyesi tarafından çekilmiş 1 . fotoğrafta da bir kurgu varmış gibi görünse de konukları etkisi altına alan güçlü bir akış söz konusudur; herkes oturduğu yere sabitlenmiş, objektifi unutmuş bir halde mumların söndürülüşünü sakin, biraz şaşkın ve merakla izlemekte. Sadece arkadan pastaya abanmaya çalışan küçük kız sabırsız bir temas halinde. Küçük olmanın avantaj ve dezavantajını bir arada yaşıyor. Akışın güçlü olduğu bir diğer fotoğraf ise 6'dır. İki çocuk mumu izleyemeye kapılmış, kamerayı unutmuş gibi görülmektedir.

Akışın güçlü olduğu fotoğrafların aynı zamanda özgünleştiği ileri sürülebilir. Örneğin 1. fotoğraftaki mum üfleyenlere yönelmiş şaşkın bakışlar, 3. fotoğraftaki kız çocuğunun gülüşü, 7. fotoğraftaysa olay akışına kendini kaptırmış aktörlerin coşkun kahkahaları ve bunun diğer öznelerde yarattığı mutlu şaşkınlık, fotoğrafları sıradan doğum günü grup portresi fotoğraflarından ayırmaktadır. Benzer kareler, yakalanmış akışla özgünleşmektedir. Fotoğrafa bakan gözler de, fotoğraf sahibinin biyografisine ihtiyaç duymadan, seyirci payını kullanarak akışı ve duyguyu tamamlar: Ne güzel bir doğum günüymüş. Herkes çok eğlenmiş. Çocuklar çok mutluymuş.

\section{Simgeler}

Simgesel antropolojiye göre, kültür, kamusal simgelerle vücut bulduğundan, bir toplumun üyeleri, simgeler aracılığıyla dünya görüşlerini, ethos yönelimlerini, birbirlerine ve gelecek kuşaklarına anlatıp iletirler. Dolayısıyla simgeler soyut olmayıp, toplumsal süreçte belirli bir uygulamanın işlem sürecinde icra edilen simgeler birer anlam aracıdır. Toplumsal aktörlerin görme, hissetme, dünyayı algılama yollarını biçimlerler. Aktörleri toplumlarının kategorileri ve kuralarıyla bağlarlar (Ortner, 1984: 129-131).

İncelenen fotoğrafları sıradan bir aile fotoğrafı ya da grup portresi olmaktan çıkaran şey de barındırdığı doğum günü ritüeline özel böylesi simgelerdir. Ritüel, "aktörün amaç ve çıkarları adına doğaüstü varlıkları ya da güçleri etkilemek için tasarlanmış, ayrılmış bir yerde icra edilmiş, jest, kelime ve nesneler gibi etkinliklerin stereotipleşmiş dizisidir” (Turner, 1973: 1100). Bu nedenle doğum gününü inceleyen halkbilimciler, kek, mumlar, şark1, hediyeler, oyunlar gibi farklı konulara odaklanabilmektedir (Brunvand, 2006: 170). Konu edilen fotoğraflara bu ritüelin şarkı, hediye, oyun gibi parçaları yansımamıştır. Göze ilk çarpan simgeyse doğum gününün alamet-i farikası olarak kabul edilen (Humphrey, 1991: 22) mumlu pastadır. Pasta, yanan mumlar (6. fotoğraf), süslemesi (7. fotoğraf), üstündeki yazılar (1. fotoğraf) ve mum üfleme ritüelinin ${ }^{3}$ (2. fotoğraf) birleştiği merkezi simgedir.

Sadece pasta değil onun verildiği bağlam da önemlidir (Humphrey, 1991: 20, 23). Bağlamın ilk unsuru, bireysel tercihlerden ziyade bir şölene uygun olan mönüdür. Fotoğrafların merkezinde yer alan pasta, bir festival sofrasına uygun olarak, oldukça düzenli, özenle hazırlanmış bir masada durmaktadır. Bir öğlen yemeği mönüsünden farklı olarak masadakiler oldukça "şekerli"dir: Masada bazen üç farklı pasta (1. fotoğraf), farklı hamur işleri (7. fotoğraf) ve meyve (2. fotoğraf) de görülmektedir.

Bağlamın diğer unsuruysa katılımcıların şölene uygun görünüş ve davranışlarıdır. Karelerdeki katılımcıların dış görünüşü ve bir araya getirilişindeki düzen, özel bir gün etkinliğine uygundur. Hatta herkes o kadar özenlidir ki doğum günü çocuğu ilk bakışta seçilememektedir. Bunun yanı 
sıra kimisi kazara görünen yetişkinler de doğum gününün toplumsal bir ritüel oluşuyla ilişkilidir. Törene katılanlar, öznesinin hem toplumsal kabul aldığının, hem de yıl boyunca yeni yaşına uygun "ahlak ve kurala dayalı pratikleri” uymasının kendisinden beklenildiğinin imasıdır.

\section{Hatıralar}

Hirsch'e göre (1997: 10-1), ailevi bakış (familial look); okurların bilip şahit olmadıkları, resme bakarak dahi elde edemedikleri bilgileri sunan, biyografi sahibinin kendisine ve ailesine, ailevi deneyim ve ilişkiler ağı içinden geriye dönüp yönelttiği yorumlayıcı bakıştır. Ancak bu bakış, gerçek hayatta mümkün olmayan bir şekilde, "zaman sıçrayışıyla" yapıldığından bireyler "sonsuz çocuk" hallerine bakabilmektedirler5. Bu sıçramalı bakış, hem fotoğrafın, hem de oto-biyografinin ortak bir kusurunu da ortaya çıkmaktadır: Temsillerini tamlık ve bütünlükle sunma yanılsaması. Aslında fotoğraf da, oto-biyografi de "sadece anlatı ve geleneksel ilişkilerde kısmen saklanabilen" parçalı bir yapıya sahiptirler ve tamamlanmamışlardır (Hirsch, 1997: 84). Makalenin bu kısmında, fotoğrafları tamamlamak üzere doğum günü çocuklarından biri ve biyografinin de sahibi olan Mustafa'nın anılarından yararlanılarak imgeler yeniden yorumlanmaktadır.

\section{Çeken Gözler}

Mustafa'nın ailesi kendi fotoğraf makinesine sahipmiş. İlk üç fotoğraf da Mustafa sünnetinde hiç ağlamadığı için ona hediyesi olarak alınan makineyle çekilmiş. Ayrıca aile bir fotoğraf stüdyosuna çekime gidebildiği gibi, özel günlerde özel bir fotoğrafçı da çağırabilmekteymiş. Söz konusu fotoğrafçı Eskişehirli İsmail Alkılıçgil ${ }^{6}$ olup makaledeki 4. ve 5. fotoğraflar ona aittir. Yani aile, kalıp pozlar geliştirebilecek kadar kadrajın önünde ve arkasında olmaya alışıktır: "Annemin böyle şeyleri vardı yani, bizi böyle allamak pullamak, ihtimam etmek; hem kız kardeşime hem bana; güzel giydirmek, yaş günleri yapmak. ... fotoğrafçı falan çağırılıp çekilirdi. ... Babam 'mahallenin fotoğrafçısını çağırır', fotoğrafçı başlangıçta gelir fotoğrafları çeker giderdi. Daha sonra biz de gider alırdık..."

Ailenin sıkça çektirdiği fotoğraflar, bir aile imgesi kuracak şekilde evin belli köşelerinde sürekli sergilenmemişlerdir. Ama aile ve arkadaş çevresinin belleklerindeki ortak anı sayısı arttırmaya yardım edecek şekilde kullanılmışlardır: "Fotoğrafların önce kutularda ve hemen sonra aile albümünde saklandığını biliyorum. Bu albümlerde bebeklik, sünnet, doğum günü fotoğrafları sırasıyla yer alıyordu. Evet, çoğunlukla anı ve aile hafızası işlevleriyle yer aldılar. Eve gelen misafirlere; yakın akrabalara; aile albümlerini izletme gibi bir alışkanlıktan ya da davranıştan bahsedilebilir. Kucaklarda, dizler üstünde büyük, büyük albümler saatlerce izlenirdi. Albümleri annem düzenliyordu ve çok meraklıydı."

\section{Yüzler}

4. fotoğraftaki çocukların hepsi Mustafa'nın mahalle arkadaşları: Ercan, Ata, Kemal, Muzaffer. Yakın arkadaşı Ertan, Mustafa'nın sol yanında, Ali’yse fotoğrafın solunda, elleri küçük bir çocuğun omuzlarında. Uzun boyu ve kravatıyla Sedat, fotoğrafın merkezinde duruyor. Temhide de sağ başta, Ali gibi ellerini bir küçük çocuğun omuzlarına koyarak simetrik kompozisyonu tamamliyor. 
1. fotoğrafta oturan ağabeyinin sırtının üzerinden olan biteni görmeye çalışan ayaktaki küçük kız Muhterem. Ama yakın arkadaşlar Ali ve Ertan o gün yok. Yine de Hülya ve Mustafa'nın “evcilik oyunu arkadaşı” Temhide var. İkisi Mustafa'nın karşısında yan yana oturmuşlar.

3. fotoğrafta, arkadaki duvarda Hayat Mecmuasının verdiği bir poster tablo; Beylerbeyi?... Babaanne, Hesna Hanım, merkezde oturmuş. Çocuklar onun iki yanında, ayakta. Fotoğraflardaki kucaklayışlar kurgu değildir. Merkezdeki babaanne sevilmiştir. Ailenin her şeyidir. Bu nedenle 3. fotoğraf, baskın ve güçlü figürlerin merkezde yer aldığ1 "kendisini geleneksel olarak tanımlayan" (Ulu, 2013: 99-100) aile fotoğraflarını anıştırmaktadır. Merkezde oturan babaanne gerçekten baskın bir karakter midir, sorusuna, biyografi sahibinin anlatımına göre, "Bir ölçüde", diye yanıt verilebilir: "Evet. ...babaannemin karşısındaki pozisyonu çocukken beni çok etkilerdi. Hep sessiz; tam Anadolu gelini; her dediğine itaat eden ve tartışmasız yerine getiren. Babaannem bu konuda, anneme göre çok huysuz bir kadındı. O huysuzluğu hiç hissetmezdik. Ama annem “çekerdim” derdi. Çünkü iktidardı, otoriteydi. Yerinden kalkmazdı. Her işini anneme yaptırırdı ve sırtını da babama dayardı. Babam da işte "annem" der, başka bir şey demezdi..."

Fotoğraf 5'teki aile büyüğü ise Uluborlu'dan bir aile dostu olan Zübeyde Totu Hanım Teyze. Mustafa, onun torunlarıyla arkadaş olduğu için doğum gününe davet edilmiş ve bir fotoğrafla bu an ve dostluk belgelenmiş.

\section{Evler}

Mustafa, babasının tayin olduğu bir kent olan Eskişehir'de 1952'de doğmuş. Babası 1965 'te başka bir yere tayin oluncaya dek bu kentte dört farklı evde oturmuş. Bu nedenle ilk dört fotoğraftaki oda, farklı evlere aittir. Ama evler birbirine yakın konumda olduğundan fotoğraflardaki konuklar büyük ölçüde aynıdır.

6. ve 7. fotoğraflardaki çocuklar da babalarının mesleği dolayısıyla farklı evlerde oturmuşlar. Mustafa 1980-1993 yılları arasında Elazı̆̆'da çalıştığından 6. fotoğrafta Zeyno'nun doğum günü Elazığ'daki evlerinde, Umur'un doğum gününe ait olan 7. fotoğrafsa 1994'te taşındıkları Ankara' da çekilmiş.

\section{Hediyeler}

Fotoğraflara yansımayan ama ilk bakışta hatırlanan şeylerden biri de hediyeler olmuştur. Doğum günü kutlamanın, ailenin yaşadığı çevrede yaygın bir gelenek olduğu anlaşılmaktadır. Mustafa, fotoğraflarda görülen arkadaşlarının da doğum günlerine gittiğini ve onlara hediyeler paketlediğini hatırlamaktadır. Doğum günlerine eli boş gelindiği olmazmış. Bir çocuğun başarılı ve akıllı bir yetişkine dönüşmesine katkı sağlayacak şekilde hediyeler çoğunlukla kitap, kimi zaman küçük zekâ oyunları, zekâ küpleri gibi oyuncaklar olurmuş. Görüldüğü gibi hediyeler, belli bir eğitim ve gelir düzeyinin seçebileceği niteliktedirler.

$\mathrm{O}$ doğum günlerinden hatırlanan iki hediye Mustafa'ya iki ayrı yetişkin tarafindan verilmiştir. Bunlardan biri babasının aldığı, genel kültür konularında (tarih, keşif ve icatlar, kıyafetler vb.) soru kartları olan, doğru cevapta 1şığın yandığı pilli bir oyun setiymiş. Annesi bu oyun setini saklamış. Böylece Mustafa'nın kendi çocukları da onunla oynayabilmiş. Diğer 
hediyeyse, Hava Kuvvetlerinde, daha sonra Türk Hava Yollarına pilotu olan alt kat komşuları Yıldız Uçmaklı'nın getirdiği, Faik Sabri Duran'ın İnsanlar Alemi, kitabıymış. Bu kitap temel eğitimi boyunca onun başvuru kaynağı olmuş.

\section{Pasta}

Mustafa'nın babası 1961'de görevli olarak gittiği Birleşik Devletler'den dönerken getirdiği şeylerden üçü, ki ikisi doğrudan görünmese de, doğum günü fotoğraflarında önemli bir yere sahiptir: Pasta yapım aletleri, desenli plastik masa örtüsü ve buzdolabı. Doğum günleri, temmuz ve ağustos aylarının sıcağında yapıldığından, içeceklerin buzlu olması unutulması zor zevklerden biriymiş. $\mathrm{O}$ dönemde her evde buzdolabı bulunmadığından, buzlu içecekler bu doğum günlerinin ayrıcalıklarından biriymiş. Doğum gününün merkezinde yer alan pastayı Mustafa'nın hemen her konuda becerikli olan annesi Remziye Hanım, Hava Kuvvetleri Kooperatifinden alınan malzemeler ve babasının getirdiği pastanın yapım aletleriyle hazırlarmış: "Doğum günü pastası. ... Şimdi o gün, kek yapıyor annem. Üzümlü kek. Ortası delikli kek kabımız var... Ama kekin üstüne de krema yapacak. Ve üstlerini süsleyecek... Babam, Amerika'dan gelirken bunu yapan bir alet, böyle bir enjektör gibi, dolduruyorsunuz. Pompa üste böyle. O alet mutfakta hep dururdu, hatırlarım. Bir o, bir de şimdi blender dediğimiz elle çırpma makinesi. Çok ilginç. Kimseciklerde yoktu. Çevirince, tı1ır, iki tane şey, böyle çeviren iki tane çırpma makinesi. Uzun yıllar o kullanıldı evde... o pastanın üstü, bakardım anneme, kremayı üstüne o pompa gibi şeyle böyle şekiller yapar, adımı yazar, 'iyi k'”, 'iyi ki doğdun' demezlerdi de işte, “doğum günün kutlu olsun”, 'iyi yaşlar', falan filan gibi şeyler, yazılar yazdığını hatırlıyorum pastanın üstüne. Çikolatayı eriterek yapardı. Bir de beyaz krema yapardı, yumurtanın akından falan. O günkü imkânlarla.”

Zaman gibi 6. ve 7. fotoğraflardaki pastalar da değişmiştir. Çalışan anne baba, çocuklarının doğum günü için profesyonel ellerden çıkmış yaş pasta satın almıştır. Pastalar özel olarak doğum günü için yapılmamışlarsa da üstlerine konan mumlar ve masa düzeni, davetlilerin çağrılış amacı, pastaları birer doğum günü pastasına çevirmiştir.

\section{VI. Üç kalıp}

"Neden benzer kareler?" sorusuna tekrar dönülebilir. Cevap aslında tektir: "Kalıp gereği”". Kalıbın kaynağı ise üç tanedir. Kalıp yaratan temel unsur sanata / zanaata ilişkindir: Kompozisyon. Diğer iki kalıp kaynağıysa fotoğrafların çekilme nedeniyle ilgilidir: Ritüel ve aile imgesi.

Gombrich'in (2015: 70-1) kalıp - tasvir, Burke'un (2003: 26-9) kalıp sistem, halk sanat1 açısındansa taklit ve çoğaltma (Jones, 1997: 56) olarak tercüme edilebilecek teknik, fotoğrafların benzer bir kompozisyona sahip olmasının nedenidir. Grup ya da aile portresinin ve doğum günü fotoğrafının, yıllar içinde geliştirilip kabul görmüş bir kalıp tasviri vardır. Üzerinde anlaşılmış bu imge düzeni sayesinde, fotoğrafın anlamı da daha ilk bakışta keşfedilebilmektedir. Doğum günü fotoğraflarındaki davetlilerden kameraya odaklanmalarının ve akıştaki ritüel davranışın bırakılarak poz verilmesinin beklenmesi, herkesin çeki düzen halinde durması, yenmek öncesi temiz masa, konuk sayısı ve fiziki durumları kadar masanın boyutu - duruş yönü - oda genişliği gibi fiziki ölçülere de bağlı olarak bir perspektifin kurulması gibi 
ortaklıklar, aynılaşmasını sağlayan kalıp tasvirin unsurlardır. Gombrich (2015: 76), kalıp tasvirin yeniden duyguyla yüklenebilmesi için "gerçek bir sanatçı" ya gerek olduğunu savunursa da, 6. fotoğraftaki mum 1şı̆̆ının yarattığı buğulu, büyülü atmosfer gibi, bazen ortamın ve şansın yarımıyla sıradan bir aile fotoğrafı bile estetik açıdan güçlü bir hale gelebilmektedir.

Ritüelin doğası da bir kalıbı izlemeyi zorunlu kılmaktadır. Doğum günü ritüeli, kamusal bir etkinlik olarak siyaset, bürokrasi, ekonomi, kavramsal sınıflamalar, inançla ilişkili olabilmektedir. ${ }^{7}$ Tören fotoğraflarının bu işlevleri bir kareye yansıtması da kalıp tasvirle yerleşen aşinalıkla mümkündür. Bunun için de fotoğraf karesinde ritüelin temel aktörleri ve unsurları (mumlu doğum günü pastası, özenli giyim, şekerli doğum günü masası, ritüelin katılımc1 ve izleyicileri) olmak zorundadır. Bu zorunluluk, ritüelin kronolojik olmayan, zamanı neredeyse tersine çeviren mitik, kutsal döngüsel zamanının da gereğidir (Eliade, 1993: 133-4). İnsan imgelerine, giyim ve süslenmeye, pasta türü ve süslemelerine vuran kronolojik zaman, ritüel düzenine ve ritüelin artık "modern" bir parçası olan fotoğraf çektirme geleneğine, vurmamaktadır. Bu nedenle otuz yıl farkla çekilen fotoğraflardaki kareler, döngüsel zamana uygun olarak benzer bir düzeni yansıtmaktadır. Bu düzen gelenek ve ritüel gibi zamana dayanıklıdır ve değişmez gibi kabul edilmektedir.

Benzer karelerin çekilmesinin son nedeniyse aile fotoğraflarıyla ilişkilidir. Aile portre resmi geleneğine dayanan, aynı zamanda bir halk sanatı olan aile fotoğrafı (Bouquet, 2000: 3, 9), üç işleve sahiptir: Kamusal ve özel alana ait olanı belgelemek; aile imgesi oluşturmak; zamanla mekâna bağlı bir aile belleği olarak anıları saklamak (Erkonan, 2014: 127-8). Bu işlevlerden aile imgesi, aile kurumuyla ilgili kültürel olarak farklılaşan, tarihsel olarak gelişen ideoloji ve mitlere yerleştirilmiş bir aile yansımasını, geleneksel bir aile resminin çerçevesinde arayıp görmek isteyen, kalıpsal ve inceleyici bir seyrediştir. Buna ailevi sabit bakış (familial gaze) da denir (Hirsch, 1997: 10-1).

Fotoğraflardaki, törene özel kullanılan yemek takımları, katılımcıların şık giysileri, yakın arkadaşlarla tören çocuğunun yan yana dizilişi, grup resimlerinde merkezde aile büyüklerinin, kucaklayıcı pozisyonda babanın oluşu, çocukların doğum gününün kutlanması, geleneksel bir aile albümünün parçası olmaya uygun fotoğrafların çekilmesi bu ailevi mitik kalıbın bir sonucu olarak yorumlanabilir.

Altı fotoğrafa (6. fotoğraf hariç) yansıyan masa düzeni, sadece bir tören masasının olması gerektiği düzeni değil, misafir ve misafir karşısındaki aile imgesini de yansıttığından birbirinin benzeridir. Örneğin, Mustafa’nın babasının Amerika Birleşik Devletleri’nden getirdiği ve uzun yıllar sadece misafirler için kullanılan plastikten desenli masa örtüsü (1., 2. ve 3. fotoğraflar), yine sadece misafir için kullanılan servis takımı ve peçeteler, "limonata" bardağı diye tanımlanan ve vitrinlerde saklanan bardaklarla ortamı süsleyen yapma çiçekler, misafir ve tören odaklı bir kalıp dekorun temel unsurlarıdır.

Fotoğraflardaki giyim ve süslenme de sadece bir törene katılındığı için özenli değildir. Pozların, "psikolojik açıdan” kabul edilebilir, görgü kuralarına uygun olması yönündeki kaygıyla (Gombrich, 2015: 115) ve bu kaygıya bağlı olarak da portre tablolarda insanların günlük giyimlerinden farklı olarak genelde en iyi giyimleriyle poz verme kalıp davranışıla ilgilidir (Burke, 2003: 27). Özellikle ilk beş doğum günü fotoğrafı böylesi özenli imgeleri yansıtmaktadır. Dolayısıyla 1960'lara ait bu fotoğraflar, hem dönem insanlarının grup etkinliklerindeki 
görünüş hassasiyetini, hem de fotoğraf sahibi ailenin güzel, özenli giyinme arzusunu yansıtan fotoğraflar olarak görülmelidir. Fotoğraflara yansıyan temiz, güzel ve düzgün giyimle biçimli saçlar kamusal nitelikli bir ritüelin ağırlığına uygun düşmektedir: 2. fotoğrafta kızlar kısa yazlık elbiseler içinde, bazı oğlanlarsa şort, gömlek ve beyaz çoraplarıyla görülüyor. 1. fotoğrafta, solda oturan Temhide'nin elbisesi, saten gibi parlak bir kumaştan. 3. fotoğrafta anne ve kızın elbisesi oldukça güzel, iyi dikimli. Mustafa fotoğraflara baktığında annesinin özel günler için kendi elleriyle dikerek hazırladığı giysileri hemen hatırlamaktadır: "O güne ait giysilerim annemin diktiği giysiler. Her doğum günümüzde ve bayramlarda yeni giysiler diker ve ilk kez o günlerde giyerdik. [4.] Fotoğraftaki gömlek bunlardan birisi. ...[3. fotoğrafta] çok sevdiğim kolları beyaz ve mavi şeritli siyah kazağım. Şimdi olsa yine giyerim!”

\section{Sonuç}

Doğum günü kutlamasının bir parçası olan fotoğraf çektirmede, kompozisyonların iki önemli geleneğin takibiyle kurgulandığı anlaşılmaktadır: Portrecilik sanatındaki kalıp-tasvir ve ritüel. Ailenin sahip olduğu kendisine ait imge de, fotoğraflarda benzer bir karelerin oluşmasına neden olabilmektedir. Bu üç tasvir kalıbı fotoğrafları ilk bakışta anlaşılabilir kılmaktaysa da onların değerini belirleyen tek etken değillerdir. Çeken gözün yaratıcılığı ve biraz şans, fotoğrafi estetik açıdan özgünleştiren unsurlardır. Anlamsal değerse hem fotoğrafların yansıttığı imgelerin etnografik nitelikleri, hem de sahiplerinin onlara sığdırdığı anılarla ilgilidir. Anılar, aynı zamanda resimlerin yeni bir boyut kazanmasını da sağlamaktadır. Böylece sıradan bir doğum günü çocuğu imgesi, arketipik bir davranışla hatırlanmaya değer, bir tören çerçevesinde yaşamı onurlandırılan bir aile ve toplum üyesine dönüşmektedir. Doğum gününe katılmış konuk grubu imgesi, bir toplumun dayanışma halindeki, ailevi ve toplumsal bir süreklilik içinde var olan tek tek bireyler haline gelmektedir. Bir doğum günü pastası imgesi ise anne emeği, tüketim ilişkileri, aile içi ilişkilerdeki sevgi ve özeninin ifadesi olmaktadır. Yani benzer kareler, yaşamların benzer olduğu yanılgısını da yaratan, kalıp tasvirlerin bir sonucudur. Anılarsa kalıp içine sıkışmış gibi görülen karelerin hiç de benzer olmadığının ifadeleridir.

\section{Notlar}

1 Etnograflarca 20. yüzyılın başından beri kullanılan biyografi ve otobiyografide, incelenen toplumun bir üyesinin ya da bir etnografın kişisel geçmişindeki yaşantı ve olaylar, etnografin gözünden ve etnografik terimlerin desteğiyle, tarihsel bağlamları içinde eleştirel bir bakışıyla değerlendirilmektedir (Fabian, 1999: 117-8, 120; Reed-Danahay, 2005; Lohmann, 2008). Bu yazıya temel olan biyografi de böylesi bir bakışın ürünü olup, öznesi o dönemki adıyla Mustafa'dır, Mustafa Muhtar Kutlu.

2 Burada kullanılan anlamıyla "Akış, üzerimizde bilincin müdahalesine ihtiyaç yokmuş gibi görünen, iç mantığa uygun olarak, eylemin eylemi izlediği bir durumdur”. Turner, 1979: 486-487.

3 Mum simgesi için bkz. Cooper, J.C. (1987). Candle, An Illustrated Encyclopedia of Traditional Symbols. London: Thames and Hudson Ltd., 28.

4 Doğum günlerinin bu işlevi konusunda bkz. Shamgar-Handelman ve Handelman, s. 293-5.

5 Fotoğrafın bu nitelikleri hakkında bkz. H. Sinisalo (1987-88). The Photograph as Research Object and Source. Ethnologia Fennica, Vol. 16, 27-42.

6 Eskişehirli gazeteci ve fotoğrafçı (1928-2003).

7 Örnek için bkz. Bolivya'daki Tsimane' Yerlileri arasında yeni bir gelenek olan doğum gününün kamusal işlevleri hk. Zycherman, A. (2016). The Public and Private Dimensions of a Birthday Party: Politics, Economics, and Food in an Amazonian Community, Food and Foodways. 24:3-4, 153-172. Birer yıla bölünmüş yaş sınıflamasının yanı sıra, reşit olma, askerlik yaşı gibi diğer resmi yaş grupları ve onlara ilişkin resmi ve kültürel beklentiler hk. Shamgar-Handelman ve Handelman, 1991. 


\section{Kaynaklar}

Berger, J. (2015). Bir fotoğrafi anlamak. B. Eyüpoğlu (Çev.). İstanbul: Metis.

Bouquet, M. (2000). The family photographic condition. Visual Anthropology Review, Vol. 16. No. 1- Spring - Summer, pp. 2-19.

Brunvand, J. H. (2006). Birthdays. American Folklore - An Encyclopedia. J.H. Brunvand (Ed.) pp. 170-172. New York: Garland.

Burke, P. (2003). Tarihin görgü tanıkları. Z. Yelçe (Çev.). İstanbul: Kitap.

Draaisma, D. (2012). Yaşlandıkça hayat neden çabuk geçer. G. Koca (Çev.). İstanbul: Metis.

Erkonan, Ş. (2014). Aile fotoğrafları: Aile belleğinin kurgulanmasında fotoğrafın rolünü etnografik yöntemle incelemek. Moment Dergisi. S. 1(2), ss. 122-147.

Eliade, M. (1993). Mitlerin özellikleri. S. Rifat (Çev.). İstanbul: Simavi.

Fabian, J. (1999). Zaman ve öteki. S. Budak (Çev.). Ankara: Bilim ve Sanat.

Gombrich, E. H. (2015). İmge ve göz. K. Atakay (Çev.). İstanbul: YKY.

Hirsch, M. (1997). Family frames. Cambridge: Harvard University.

Humphrey, T.C. (1991). A Family celebrates a birthday: Of life and cakes, We gather together - Food and Festival in American Life. T.C. Humphrey and L.T. Humphrey (Eds.) pp. 19-26. Logan: Utah State University.

Jones, M. O. (1997). Art, folk. Folklore - Vol. I. T. A. Green (Ed.). pp. 56-61. Santa Barbara: ABCCLIO.

Kroeber, A. L. and C. Kluckhohn (1952). Culture - A critical review of concepts and definitions. Cambridge: The Museum.

Lohmann, R. I. (2008). Introduction: Biographies of antropologists as anthropological data. Reviews in Anthropology, Vol. 37, pp. 89-101.

Ortner, S. B. (1984). Theory in anthropology since the sixties. Comparative Studies in Society and History, Vol. 26, No. 1-Jan., pp. 126-166.

Panofsky, E. (1995). İkonografi ve ikonoloji. E. Akyürek (Çev.). İstanbul: Afa.

Reed-Danahay, D. (2005). Autobiography, intimacy, and ethnography. Handbook of Ethnography. (P. Atkinson, A. Coffey, S. Delamont, J. Lofland and L. Lofland (Ed.). pp. 407-425. London: Sage.

Shamgar-Handelman, L. and Handelman, D. (1991). Celebrations of bureaucracy: Birthday parties in Israeli kindergartens. Ethnology, Vol. 30. No. 4, pp. 293-312.

Turner, V. W. (1973). Symbols in African ritual. Science, Vol. 179. No. 4078, pp. 1100-5.

Turner, V. W. (1979). Frame, flow and reflection: Ritual and drama as public liminality. Japanese Journal of Religious Studies, Vol. 6. No. 4, pp. 465-499.

Ulu, M. (2013). Dügün ve aile fotoğraflart. İstanbul: Kitap.

Wang, L., P. Alasuutari and J. Aro (2014). Aesthetic and family frames in the online sharing of children's birthday photos. Visual Communication, Vol 13(2). pp. 191-209.

Yıldırım, İ. (2013). Etnografik alan çalışmalarında görüntü kaydının kullanımı. Milli Folklor, Y. 25. S. 97, ss. 111-121. 